\title{
ANALISIS PENGARUH KEPUASAN KERJA, BUDAYA ORGANISASI DAN KOMPETENSI TERHADAP ORGANIZATIONAL CITIZENSHIP BEHAVIOR PADA PT. MUBARAK AINAMA KUNT SURABAYA
}

\author{
Khoirul Mahmudi \\ Universitas Negeri Surabaya \\ khoirulmahmudi@mhs.unesa.ac.id \\ Jun Surjanti \\ Universitas Negeri Surabaya \\ junsurjanti@unesa.ac.id
}

\begin{abstract}
This study aims to examine and analyze the influence of job satisfaction, organizational culture, dan competence on Organizational Citizenship Behavior in PT. Mubarak Ainama Kunt Surabaya. This research is quantitative. The data that will be used in this study is systematic data (numbers) which will produce conclusions that can be generalized. The data in this study use primary and secondary data. Primary data in the form of data obtained through questionnaires to 42 respondents as research samples and secondary data in the form of data company profile company. The statistical analysis used in this study is multiple linear regression. The measurement scale of this study uses a Likert scale The results of this study are job satisfaction has a significant positive effect on Organizational Citizenship Behavior. This shows that better job satisfaction in the company, the higher the Organizational Citizenship Behavior felt by employees. Organizational culture has a significant positive effect on Organizational Citizenship Behavior. This shows that the better the organizational culture in the company, the higher the Organizational Citizenship Behavior felt by employees. Competence has no significant effect on Organizational Citizenship Behavior. Implementation of competencies is carried out conditionally according to the needs of the company not bound by a certain period. This shows that the good or bad implementation of competencies in the company will not affect the increase or decrease in Organizational Citizenship Behavior employees at PT. Mubarak Ainama Kunt Surabaya.
\end{abstract}

Keywords: competence; job satisfaction; organizational citizenship behavior; organizational culture.

\section{PENDAHULUAN}

Dalam era global yang terjadi sekarang, kemajuan suatu ilmu pengetahuan dan teknologi meningkat secara sangat pesat sehingga menuntut perusahaan untuk meningkatkan produktivitas kerja. Produktivitas mempunyai dampak terhadap kegiatan lainnya. Produktivitas mampu meningkatkan kepuasan kerja, melecut terjadinya penyederhanaan kerja, meningkatkan keterpaduan, dan spesialisasi kerja. meningkatnya produktivitas, di samping memberikan kepuasan kerja kepada pekerja individu atau kelompok, juga mendorong mereka untuk meningkatkan kinerja lebih baik lagi, untuk meningkatkan kinerja ada banyak faktor yang dapat memengaruhi kinerja, diantaranya adalah manajemen sumber daya manusia (Huda, 2018).

Indonesia sebagai negara berkembang merasakan dampak dari globalisasi dan perkembangan teknologi terutama segi perekonomian. Dengan perekonomian yang semakin maju, maka kesejahteraan masyarakat akan mengalami perkembangan. Sebagai upaya untuk menstabilkan perekonomian dan mengahadapi persaingan dunia bisnis, negara Indonesia bergabung dengan Masyarakat Ekonomi ASEAN pada tahun 2015, dengan bergabungnya negara Indonesia dengan MEA diharapkan dapat meningkatkan skala ekonomi dalam negeri melalui perdagangan di pasar bebas. Adapun dampak yang yang ditimbulkan dengan adanya MEA yaitu semakin tingginya persaingan bisnis domestik maupun internasional, karena produk-produk luar negeri sudah merambah pada pasar domestik Indonesia (Suhardi \& Syaifullah, 2017).

Untuk dapat bertahan di era globalisasi ini yang persaingannya semakin ketat itu memaksa perusahaan untuk menjadi yang terbaik dari yang baik. Salah satu upaya yang ditempuh agar perusahaan dapat tumbuh berkembang dan menjadi yang terbaik, adalah dengan meningkatkan keunggulan bersaing. 
Khoirul Mahmudi \& Jun Surjanti, Analisis Pengaruh Kepuasan Kerja, Budaya Organisasi dan Kompetensi terhadap Organizational Citizenship Behavior pada PT. Mubarak Ainama Kunt Surabaya

Kinerja pemasaran dihasilkan dari interaksi intelektual jajaran sumber daya manusia sesuai dengan standarisasi kompetensi disyaratkan (Suhardi \& Syaifullah, 2017).

Organizational citizenship behavior dianggap vital bagi eksistensi organisasi (Husodo, 2018). Organizational CItienship Behavior adalah kontribusi individu yang melebihi dari tuntutan peran ditempat kerja dan mendapatkan reward atas kinerjanya (Dewanggana, Paramita, \& Haryono, 2016). Organizational CItienship Behavior merupakan perilaku karyawan yang melebihi peran yang diwajibkan, yang tidak secara langsung atau eksplisit diakui oleh sistem reward formal merupakan perilaku pilihan yang tidak menjadi bagian dari kewajiban kerja formal seorang karyawan, namun mendukung berfungsinya organisasi tersebut secara efektif. Organizational Citizenship Behavior dapat timbul dari berbagai faktor dalam organisasi, di antaranya karena adanya kepuasan kerja dari karyawan dan komitmen organisasi yang tinggi (Dewi \& Suwandana, 2016).

Fattah (2017) menunjukkan bahwa kepuasan kerja merupakan gambaran dari perasaan bahagia maupun tidak bahagia seorang pegawai terhadap apa yang dilakukan atau dikerjakan. Karyawan yang mengalami kepuasan mengenai pekerjaan yang sedang dijalani, hingga pegawai hendak bekerja smaksimum mungkin. Selain disebabkan akibat kepuasan kerja, organizational citizenship behavior pun dapat dipengaruhi budaya organisasi. Menurut Utaminingsih (2014), budaya organisasi menggambarkan serangkaian nilai-nilai, norma dan asumsi-asumsi yang dimiliki karyawan dalam bekerja sehingga dapat membedakan tiap-tiap perusahaan. Fokus dari budaya organisasi adalah perilaku karyawan demi meningkatkan kapabilitas kerja, commitment dan loyality, serta perilaku extra roll. Keuntungan mengenai implementasi budaya organisasi yang bagus ialah sanggup meningkatkan semangat bahu-membahu, membangun hubungan yang lebih baik, meningkatkan kebersamaan, meningkatkan jiwa kekeluargaan, satu sama lain saling terbuka, meningkatkan work productivity, kritis terhadap perubahan dunia luar, yang sebagian besar menggambarkan kepingan dari organizational citizenship behavior (Oemar, 2013).

Terdapat variabel lain yang mampu memengaruhi organizational citizenship behavior yaitu kompetensi, kompetensi ialah sebuah karakteristik landasan yang dimiliki individu dengan mengidentifikasi sikap, tindakan, cara individu berpikir serta penarikan kesimpulan hingga pihaknya mampu mempertahankan pada waktu-waktu yang tidak diketahui (Pianda, 2018).

Dari data internal perusahaan dapat dilihat jumlah kompensasi yang diterima karyawan pada tahun 2019 khususnya insentif tidak begitu memuaskan, ini dikarenakan insentif yang diterima karyawan setiap bulannya tidak diterima karyawan seluruhnya. Hal ini diharapkan tidak memengaruhi semangat kerja karyawan untuk memberikan kinerja yang terbaik kepada perusahaan. Menurunnya pemberian kompensasi biasanya berdampak terhadap kepuasan kerja karyawan karena kompensasi berguna untuk memenuhi kebutuhan hidup karyawan. Selain kompensasi menurut wawancara dan observasi cara perusahaan memberikan suatu kepuasan kerja bagi karyawan adalah dengan adanya promosi jabatan, promosi jabatan diberikan kepada karyawan yang bekerja dengan baik dan memiliki kinerja yang baik sesuai dengan standar yang telah ditetapkan oleh PT. Mubarak Ainama Kunt Surabaya.

Dari hasil observasi dan wawancara jenis promosi jabatan yang diberikan PT. Mubarak Ainama Kunt Surabaya tidak terlalu banyak, hal ini dikarenakan menurunnya kinerja yang dihasilkan perusahaan yang disebabkan oleh kurangnya kepuasan kerja karyawan terhadap perusahaan. Ini harus menjadi perhatian bagi perusahaan untuk bisa meningkatkan kepuasan kerja karyawan agar para karyawan dapat dengan nyaman menjalankan tugas dan tanggung jawab yang telah diberikan. Menurut data internal perusahaan dan wawancara jumlah karyawan PT. Mubarak Ainama Kunt Surabaya pada tahun 2020 mengalami penurunan, ini dapat disebabkan oleh menurunnya kepuasan kerja karyawan terhadap perusahaan sehingga karyawan lebih tertarik untuk bekerja di perusahaan yang lainnya.

Dalam menghadapi ketatnya persaingan bisnis, perusahaan juga memperhatikan budaya organisasi yang terbentuk di perusahaan. Dari hasil observasi awal, budaya organisasi sudah berjalan dengan baik, seperti karyawan dalam melayani customer sesuai dengan standard operational procedure (SOP) yang ada. Selain itu, karyawan dalam bekerja juga memakai perlengkapan yang sudah 
ditentukan seperti rompi, sepatu safety, helm safety dan lain sebagainya. Budaya organisasi yang terbentuk di PT. Mubarak Ainama Kunt dapat dilihat dari perilaku karyawan. Contoh sederhana ketika setelah selesai bekerja, karyawan diminta untuk membiasakan membersihkan dan merapikan terlebih dahulu peralatan kerja. Hal ini bertujuan selain untuk menjaga peralatan yang dimiliki perusahaan, juga untuk menciptakan rasa memiliki karyawan dimana peralatan kerja perusahaan adalah peralatan kerja milik mereka sendiri.

Terbentuknya budaya organisasi, juga dapat dilihat ketika karyawan akan memulai bekerja selalu mengadakan briefing dan berdoa tanpa menunggu pimpinan datang. Contoh lain dari terbentuknya budaya organisasi di PT. Mubarak Aimana Kunt yaitu saat menggunakan baju seragam saat bekerja, baik untuk seragam lapangan maupun seragam kantor. Namun budaya organisasi yang ada belum maksimum dan berlangsung buruk pada PT. Mubarak Ainama Kunt Surabaya, seperti belum disiplinnya pegawai dalam menjalankan pekerjaannya, seperti contoh saat jam masuk kerja yang semestinya pegawai sedah memulai suatu pekerjaan tapi sebaliknya para pegawai bersantai-santai untuk menikmati sarapanmakan pagi atau hanya sekedar berbincang dengan pegawai yang lain.

Data yang ada pada PT. Mubarak Ainama Kunt Surabaya menunjukkan bahwa dapat diketahui dari 42 jumlah karyawan PT. Mubarak Ainama Kunt hanya 19\% karyawan yang memiliki sertifikasi keahlian, sedangkan $81 \%$ karyawan masih belum memiliki sertifikasi keahlian. Selain itu background pendidikan terakhir para karyawan yaitu 50\% lulusan SMK, 20 \% lulusan SMA, dan 30\% lulusan S1. Dengan adanya karyawan yang memiliki sertifikasi tersebut, diharapkan dapat membantu pelaksanaan kerja karyawan baik secara individu maupun tim. Tidak hanya itu, batas minimal pendidikan setiap calon karyawan yang ingin bergabung di perusahaan yaitu setara dengan Sekolah Menangah Atas.

Berdasarkan hasil wawancara dengan HRD mengenai organizational citizenship behavior, tingkat organizational citizenship behavior pada karyawan PT. Mubarak Ainama Kunt Surabaya dikategotikan belum cukup tinggi dan ditunjukkan terdapat masalah pada organizational citizenship behavior. Kurangnya motivasi pada diri karyawan yang membuat karyawan tersebut tidak selalu bekerja keras dalam menyelesaikan tugas-tugas dan pekerjannya (Conscientiousness), inisiatif untuk membantu rekan kerja yang tidak masuk atau karena berhalangan kerja masih dapat dikatakan rendah. Biasanya atasan harus memberi instruksi terlebih dahulu baru kemudian karyawan membantu menyelesaikan pekerjaan tersebut (Altruism), kurangnya ada partisipasi karyawan dalam sebuah kegiatan diluar jam kerja, biasanya karyawan akan ikut berpartisipasi jika kegiatan tersebut menarik dan memberikan keuntungan bagi dirinya (Civic Virtue), tidak semua karyawan dapat memberikan toleransi kepada rekan kerjanya, dan tidak semua karyawan ingin bertahan di dalam perusahaan (Sportmanship), kurangnya kebijakan dalam menyelesaikan masalah dan kurangnya komitmen dengan perusahaan membuat indikator ini masih dapat dikatakan kurang baik (Courtesy).

Penelitian ini bertujuan untuk menguji serta menganalisis pengaruh Kepuasan Kerja, Budaya Organisasi dan Kompetensi terhadap Organizational Citizenship Behavior di PT. Mubarak Ainama Kunt Surabaya.

\section{KAJIAN PUSTAKA DAN PENGEMBANGAN HIPOTESIS}

\section{Kepuasan Kerja}

Osman et al. (2015) mendefinisikan kepuasan kerja sebagai pemenuhan dan pemuasan kebutuhan tertentu yang terkait dengan pekerjaan seseorang. Sedangkan menurut Utami \& Palupiningdyah (2016), kepuasan kerja merupakan sebuah tanggapan afektif atau emosional terhadap berbagai segi pekerjaan seseorang, dan kepuasan kerja yang dimiliki individu mencerminkan tingkat dimana seseorang menyukai pekerjaannya.

Terdapat dua faktor yang menyebabkan kepuasan dan ketidakpuasan, yaitu sebagai berikut. (1) Faktor Motivator merupakan karakteristik pekerjaan berkaitan dengan kepuasan pekerjaan, yaitu sejumlah kebutuhan yang apabila dipenuhi akan menimbulkan kepuasan tetapi jika tidak dipenuhi akan 
Khoirul Mahmudi \& Jun Surjanti, Analisis Pengaruh Kepuasan Kerja, Budaya Organisasi dan Kompetensi terhadap Organizational Citizenship Behavior pada PT. Mubarak Ainama Kunt Surabaya

mengurangi kepuasan. (2) Faktor Hygiene merupakan karakteristik pekerjaan berkaitan dengan ketidakpuasan pekerjaan, yaitu sejumlah kebutuhan yang apabila dipenuhi tidak akan meningkatkan motivasi, tetapi jika tidak dipenuhi akan menimbulkan kepuasan (Darmawati \& Indartono, 2015).

Menurut Yasa \& Suandra (2017), kepuasan kerja bisa diukur menggunakan lima indikator di antaranya: (1) Upah, merupakan imbalan karyawan terkait dengan apresiasi bentuk timbal balik atas apa yang dikorbankan untuk perusahaan apakah pantas atas kebutuhan yang dirasakan adil atau tidak. (2) Promosi, yaitu kemungkinan seorang karyawan untuk dapat berkembang malalui kenaikan jabatan. (3) Rekan kerja, yaitu orang yang berada disekitar karyawan yang senantiasa berinteraksi dalam bekerja. Seorang bisa merasakan teman kerja yang dimiliki membuat perasaan menjadi sennag atau tidak. (4) Atasan, merupakan seseorang yang memberikan arahan dan petunjuk di lingkup pekerjaan, dan (5) Pekerjaan itu sendiri, merupakan deskripsi pekerjaan yang menjadi tanggung jawab individu apakah memberikan kepuasan atau tidak.

\section{Budaya Organisasi}

Budaya organisasi didefinisikan dalam tiga hal. Pertama, budaya adalah sebuah persepsi bukan sesuatu yang dapat disentuh atau dilihat secara fisik, namun para karyawan menerima dan memahaminya melalui apa yang mereka alami dalam organisasi. Kedua, budaya organisasi bersifat deskriptif yaitu berkenaan dengan bagaimana para anggota menerima dan mengartikan budaya tersebut. Ketiga, meskipun individu dalam organisasi berlatar belakang yang berbeda dan jenjang organisasi yang juga berbeda karyawan cenderung mengartikan dan mengutarakan budaya organisasi dengan cara yang sama (Utami \& Palupiningdyah, 2016). Sedangkan menurut Husodo (2018) budaya organisasi adalah filosofi, ideologi, nilai, asumsi, kepercayaan, harapan, sikap, dan norma bersama yang, merangkul suatu organisasi

Menurut Mulyadi \& Sembiring (2016), terdapat faktor-faktor yang memengaruhi praktik budaya organisasi, antara lain sebagai berikut. (1) Involvement atau keterlibatan, menunjukkan bahwa organisasi punya karakteristik tertentu yang membuat karyawan memiliki keterlibatan pada organisasi dan punya rasa memiliki organisasi serta tanggung jawab. (2) Consistency atau konsistensi, di mana perusahaan dianggap efektif bilamana organisasi fokus untuk mengkoordinasikan dan mengintegrasi karena konsistensi dianggap sebagai hal utama dalam integrasi, kontrol dan organisasi. (3) Adaptability atau adaptasi, di mana organisasi diharapkan untuk terus menerapkan norma sebagai dukungan kapasitas organisasi dalam menginterpretasikan, menerima serta menerjemahkan tandatanda di lingkungan pada upaya untuk merubah sikap. (4) Mission atau misi, di mana perusahaan yang mencapai kesuksesan akan mempunyai tujuan dan sasaran secara jelas sebagai upaya untuk mencapai tujuan perusahaan, di mana adanya perencanaan yang matang menunjukkan tentang visi perusahaan pada masa mendatang.

Indikator yang digunakan dalam variabel budaya organisasi ialah indikator yang dikembangkan dari penelitian Suwibawa et al. (2018), indikator tersebut memiliki kesesuaian pada fakta yang terjadi di PT. Mubarak Ainama Kunt Surabaya, indikator pengukuran budaya organisasi menurut Suwibawa et al. (2018), menjadi enam indikator yang akan dibagi menjadi beberapa pernyataan, yakni sebagai berikut. (1) Inovasi dan pengambilan risiko, yaitu tingkatan yang menunjukkan bahwa karyawan harus memiliki inovasi tinggi dan mampu menerima berbagai risiko yang ada. (2) Perhatian yang terperinci, menunjukkan bahwa karyawan mampu untuk tepat di kondisi tertentu. (3) Orientasi hasil, yaitu menunjukkan tentang kondisi pimpinan yang mengharapkan karyawan mampu untuk fokus di hasil kerja. (4) Orientasi individu, menunjukkan tentang manajemen perusahaan yang memiliki keputusan untuk memengaruhi karyawan perusahaan. (5) Orientasi tim, yaitu menunjukkan bahwa pekerjaan itu dapat diatur berdasarkan pada tujuan bersama dan bukan atas kemauan individu. (6) Agresivitas, yaitu sejauh mana karyawan untuk aktif bersaing dalam bekerja.

\section{Kompetensi}

Kompetensi adalah suatu kemampuan untuk melaksanakan atau melakukan suatu pekerjaan yang dilandasi atas keterampilan dan pengetahuan serta di dukung oleh sikap kerja yang dituntut oleh pekerjaan tersebut. Kompetensi merupakan landasan dasar karakteristik orang dan mengindikasikan 
cara berperilaku atau berpikir, menyamakan situasi, dan mendukung untuk periode waktu cukup lama (Adianita et al., 2017). Sedangkan menurut Rande (2016) menjelaskan bahwa kompetensi dapat didefinisikan sebagai bakat yang diperlukan untuk meningkatkan kemampuan dasar dan untuk meningkatkan kinerja ke tingkat yang lebih tinggi.

Sementara itu, menurut Pattiasina et al. (2016) kompetensi menunjukkan keterampilan atau pengetahuan yang dicirikan oleh profesionalisme dalam suatu bidang tertentu dan diaplikasikan guna meningkatkan manfaat yang disepakati. Kompetensi juga menunjukan karakteristik pengetahuan dan keterampilan yang dimiliki atau dibutuhkan oleh setiap individu yang memampukan mereka melakukan tugas dan tanggung jawab mereka secara efektif dan meningkatkan standar kualitas profesional dalam pekerjaan mereka. Kompetensi menjelaskan apa yang dilakukan orang ditempat kerja pada berbagai tingkatan dan memperinci standar masing-masing tingkatan, mengidentifikasi karakteristik pengetahuan dan keterampilan yang diperlukan oleh individu yang memungkinkan menjalankan tugas dan tanggung jawab secara efektif dalam mencapai standar kualitas profesional dalam bekerja.

Kompetensi yang dimiliki karyawan dalam bekerja akan memberikan manfaat sebagai berikut. (1) Membantu dalam memenuhi kebutuhan individu, misalnya membantu dalam memberikan arahan pada penerapan perilaku hingga keterampilan karyawan dapat bertambah. (2) Penggunaan standar kompetensi sebagai penunjang kebijakan perusahaan, misalnya pada seleksi calon karyawan terbaik, (3) Memaksimalkan produktivitas, adanya standar kompetensi diharapkan dapat menstimulus karyawan menjadi lebih efektif dan membantu dalam pencarian karyawan yang mampu dibantu agar berkembang dan memenuhi ketimpangan keterampilan yang dimiliki. (4) Dasar pengembangan sistem remunerasi, di mana kompetensi dimanfaatkan untuk pengembangan remunerasi atau pemberian imbalan yang lebih menerapkan prinsip keadilan. (5) Memudahkan adaptasi terhadap perubahan, menunjukkan bahwa adanya perubahan pada lingkungan perusahaan akan memengaruhi pekerjaan yang ditekuni serta model kebutuhan terkait dengan kemampuan baru yang juga mengalami peningkatan. (6) Menyesuaikan perilaku kerja dengan nilai-nilai perusahaan, di mana kompetensi dianggap sebagai media yang mudah untuk menyampaikan nilai serta berbagai hal yang jadi fokus utama di dalam pelaksanaan kerja (Syaroni, 2015:84-85).

Sementara itu, menurut Kurniawan et al. (2018), arti kompetensi dapat dibedakan menjadi 4, yaitu sebagai berikut. (1) Unconscious incompetence, apabila individu tidak menyadari bahwa ia tidak mampu melakukan sesuatu. (2) Conscious incompetenc, apabila seseorang menyadari bahwa dia tidak mampu melakukan sesuatu. (3) Conscious competence, apabila seseorang mampu mengerjakan sesuatu dengan sangat hati-hati. (4) Unconscious competence, apabila seseorang dapat melakukan pekerjaan dengan sangat baik sehingga bahkan ia dapat melakukannya secara otomatis.

Ada lima karakteristik atau indikator kompetensi menurut Priyono et al. (2016), yaitu sebagai berikut. (1) Motif, yaitu mengacu pada sesuatu yang dipikirkan dan diharapan secara konsisten yang dapat merangsang tindakan. (2) Sifat, menunjukkan pada ciri fisik dan respon secara konsisten pada kondisi serta penerimaan informasi. (3) Konsep diri, yaitu mengacu pada nilai, perilaku dan citra karywan dalam berpikir, bicara dan bertindak. (4) Pengetahuan, menunjukkan pada penguasaan informasi dan materi oleh karyawan yang diperoleh dari pendidikan maupun dari pengalaman. (5) Keterampilan, yaitu mengacu pada kemampuan untuk melakukan pekerjaan fisik maupun mental.

\section{Organizational Citizenship Behavior}

Organizational citienship behavior menunjukkan tentang seberapa besar usaha karyawan yang berlebih terhadap tuntutan pekerjaan serta mendapatkan reward atas kinerjanya (Dewanggana et al., 2016). Organizational citizenship behavior sebagai tindakan karyawan terhadap perusahaan yang terlalu maksimal dibandingkan dengan tuntutan normal dari pekerjaan yang ditekuni. Terdapat tiga komponen utama, di antaranya (Darmawati \& Indartono, 2015). (1) Perilaku yang ditunjukkan melebihi aturan dan job description pekerjaan yang harus diselesaikan. (2) Tindakan tersebut tidak 
Khoirul Mahmudi \& Jun Surjanti, Analisis Pengaruh Kepuasan Kerja, Budaya Organisasi dan Kompetensi terhadap Organizational Citizenship Behavior pada PT. Mubarak Ainama Kunt Surabaya

memerlukan pelatihan khusus, atau melakukan tindakan dengan sukarela. (3) Tindakan yang dilakukan belum tentu atau tidak dihargai dengan imbalan formal dalam perusahaan.

Terdapat beberapa dimensi untuk menilai organizational citizenship behavior, yaitu sebagai berikut (Suwibawa et al., 2018). (1) Altruisme, yaitu perilaku karyawan dalam mengehadapi kesulitan dan situasi yang sedang dihadapkan dengan tugas. Dimensi ini dapat mengarah pada pengucilan karyawan yang tidak berhak atas kewajiban. (2) Civic virtue, yaitu perilaku yang menunjukkan tanggungjawab dan sedang terlibat dalam kehidupan perusahaan. Partisipasi dan dukungan partisipasi dalam memeliharan perusahan untuk kebaikan dalam kondisi baik. (3) Conscientiousness, yaitu perilaku yang dilakukan secara langsung hingga jatuh dibelakang aturan yang terlibat dalam perusahaan. Menunjukkan kepada mereka meningkatkan cara mereka melakukan pekerjaan untuk mencapai tujuan perusahaan. Dengan bertindak yang menguntungkan perusahaan di luar apa yang dibutuhkan. (4) Courtesy, yaitu perilaku sopan santun yang menunjukkan sosialisasi dengan cara diskusi sebelum mengambil keputusan. Mempertahakan hubungan yang dengan rekan kerja untuk menghindari masalah interpersonal. Dimensi ini dapat diwujudkan pada perilaku menghargai dan peduli dengan orang lain. (5) Sportsmanship, yaitu perilaku yang menunjukan bahwa seseorang menginginkannya mentolerir ketidakhadirannya untuk membuat kerusakan.

Organizational citizenship behavior diukur berdasarkan indikator yang terdiri dari Ramadhan et al. (2018). (1) Conscientiousness, yaitu proses kognitif yang dapat menghasilkan perasaan sesuai dengan ketentuan atau aturan yang berlaku. (2) Altruism, yaitu perilaku membantu rekan kerja, (3) Civic virtue, yaitu sikap keterlibatan karyawan dengan perusahaan. Perilaku ini sebagai wujud kontribusi aktif dari karyawan di lingkup organisasi, seperti datang pada saat diskusi, menggali isu-isu terbaru terkait persaingan perusahaan, dan lain-lain. (4) Sportsmanship, yaitu perilaku karyawan untuk lebih menekankan pada apsek positif dalam organisasi. (5) Courtesy (sopan santun), yaitu sikap baik yang ditujukan untuk menghormati pihak lain.

\section{Hubungan antar Variabel}

Kepuasan kerja merupakan gambaran dari persaan senang maupun tidak senang seorang karyawan terhadap apa yang dilakukan atau dikerjakan. Karyawan yang merasa puas memiliki sikap, perasaan dan tingkah laku yang positif terhadap pekerjaan yang dijalaninya (Fattah, 2017). Dalam penelitian yang dilakukan Darmawati \& Indartono (2015), diperoleh hasil bahwa kepuasan kerja berpengaruh positif dan signifikan terhadap OCB karyawan. Artinya kepuasan yang diperoleh baik melalui upah/gaji, promosi jabatan, dan rekan kerja akan dapat meningkatkan OCB. Selaras dengan penelitian yang dilakukan Dewi \& Suwandana (2016), dimana kepuasan kerja berpengaruh positif dan signifikan terhadap OCB.

\section{H1: Kepuasan kerja berpengaruh signifikan positif terhadap organizational citizenship behavior.}

Budaya organisasi merupakan serangkaian nilai-nilai, norma dan asumsi-asumsi yang dimiliki karyawan dalam bekerja sehingga dapat membedakan perusahaan satu dengan perusahaan yang lainnya. Budaya organisasi yang baik akan mendorong perilaku karyawan untuk menjadi lebih baik (Utaminingsih, 2014). Dalam penelitian yang dilakukan Dewanggana et al. (2016), diperoleh hasil bahwa budaya organisasi berpengaruh positif dan signifikan terhadap OCB. Artinya semakin baik budaya organisasi dalam perusahaan, maka perilaku OCB semakin meningkat. Diperkuat dengan penelitian yang dikemukakan Husodo (2018), dimana budaya organisasi memiliki pengaruh signifikan terhadap OCB.

H2: Budaya organisasi berpengaruh signifikan positif terhadap organizational citizenship behavior.

Kompetensi merupakan sebuah karakteristik dasar yang dimiliki individu dengan mengidentifikasi cara berfikir, bersikap, bertindak dan menarik kesimpulan yang dapat dilakukan dan dipertahankan oleh individu pada waktu tertentu. Dengan kompetensi yang dimiliki, seorang karyawan dapat bertindak semampunya sebagai upaya mencapai tujuan (Pianda, 2018). Dalam penelitian yang dilakukan Nugraha \& Adnyani (2018), diperoleh hasil bahwa kompetensi berpengaruh positif dan 
signifikan terhadap OCB. Artinya semakin tinggi kompetensi yang dimiliki karyawan, maka OCB semakin tinggi. Karena dengan kompetensi yang dimiliki, karyawan dapat bertindak baik positif maupun negatif terhadap tugas dan tanggungjawan yang diterimanya.

H3: Kompetensi berpengaruh signifikan positif terhadap organizational citizenship behavior.

Membangun kepuasan kerja secara optimal memunculkan akibat yang positif terhadap organizational citizenship behavior yang dirasa pekerja karena kebutuhan karyawan dalam bekerja telah dipenuhi oleh perusahaan. Serta pelaksanaan budaya organisasi yang tepat diselaraskan dengan keadaan dan apa yang menjadi kebutuhan organisasi akan rasa organizational citizenship behavior dapat terbentuk. Dan juga kompetensi yang diterapkan tepat pada organisasi akan timbul rasa organizational citizenship behavior.

H4: Kepuasan kerja, budaya organisasi, dan kompetensi berpengaruh signifikan terhadap organizational citizenship behavior.

\section{METODE PENELITIAN}

Penelitian ini termasuk kedalam jenis penelitian kuantitatif. Dalam riset ini, populasi mencakup jumlah keseluruhan karyawan PT. Mubarak Ainama Kunt Surabaya yang berjumlah 42 orang. Sebab total populasi di bawah 100, maka keseluruhan populasi digunakan menjadi sampel dengan teknik sampling jenuh. Lokasi dalam penelitian ini ialah PT. Mubarak Ainama Kunt Surabaya, yang berlokasi di jalan Greges Barat Blok A-32, Surabaya.pada penelitian ini pengolahan datanya menggunakan uji regresi klinier berganda yang di uji menggunakan aplikasi SPSS.

\section{HASIL DAN PEMBAHASAN}

\section{Deskripsi Responden}

Responden pria dengan jumlah 31 orang $(74 \%)$ dan wanita 11 orang $(26 \%)$. Terkait demikian, mayoritas responden berjenis kelamin pria pada kisaran usia 18 sampai 26 tahun berjumlah $15(46 \%)$, kisaran usia 27 sampai 35 tahun berjumlah (40\%), kisaran usia 36 sampai 44 tahun berjumlah 7 (17\%), kisaran usia > 45 tahun berjumlah $3(7 \%)$. Terkait dengan status responden, responden dengan status menikah berjumlah $22(52 \%)$ dan responden dengan ststus belum menikah berjumlah $20(48 \%)$. Maka mayoritas responden penelitian ini adalah berstatus menikah.

Dari segi tingkat pendidikan, responden yang memiliki jenjang pendidikan SLTA derjumlah 16 (38\%), tingkat pendidikan D3 berjumlah 13 (33\%), tingkat pendidikan S1 dengan jumlah 9 (24\%), tingkat pendidikan S2 dengan jumlah $2(5 \%)$, tinggkat pendidikan S2 berjumlah $0(0 \%)$. Maka mayoritas responden penelitian ini adalah tingkat pendidikan SLTA.

Berdasarkan lamanya masa kerja, responden yang memiliki masa kerja $<1$ tahun berjumlah $10(24 \%)$, masa kerja 1 sampai 2 tahun berjumlah 14 (33\%), masa kerja 3-4 tahun dengan jumlah 13 (31\%), masa kerja > 5 tahun berjumlah 5 (12\%0. Maka mayoritas responden penelitian ini adalah memiliki masa kerja antara 1 sampai 2 tahun.

\section{Analisis Data}

Tingkat indikator kepuasan kerja pada PT. Mubarak Ainama Kunt Surabaya termasuk dalam golongan yang tinggi. Dari indikator penelitian yang terdiri dari kepuasan pada upah, promosi, rekan kerja, atasan dan pekerjaan yang ditekuni memiliki nilai mean tinggi yaitu 4,2. Indikator yang memperoleh mean tertinggi adalah kepuasan dengan upah yaitu sebesar 4,15, maka kualitas upah atau gaji karyawan PT. Mubarak Ainama Kunt Surabaya dalam kondisi yang baik.

Indikator kepuasan dengan promosi memiliki nilai rata-rata tinggi sebesar 4,29, maka dapat ditarik garis besar bahwa promosi kerja yang diterapkan dalam perusahaan berefek positif pada karyawan. 
Khoirul Mahmudi \& Jun Surjanti, Analisis Pengaruh Kepuasan Kerja, Budaya Organisasi dan Kompetensi terhadap Organizational Citizenship Behavior pada PT. Mubarak Ainama Kunt Surabaya

Indikator kepuasan dengan rekan kerja memiliki nilai mean tinggi yaitu 4,17, maka adanya rekan kerja yang baik dan saling membantu dalam lingkungan kerja terjalin baik.

Indikator kepuasan dengan atasan memiliki nilai tinggi yaitu 4,26, maka karyawan memiliki rasa puas atas hubungan baik dengan atasan. Indikator kepuasan pada pekerjaan itu sendiri memiliki nilai mean tinggi sebesar 4,21, maka sebuah pekerjaan yang dibebankan oleh perusahaan pada karyawan memiliki kesesuaian dengan harapan karyawan.

Tingkat indikator budaya organisasi pada PT. Mubarak Ainama Kunt Surabaya termasuk dalam golongan yang tinggi. Dari enam indikator yang meliputi inovasi dan mengambil resiko, adanya perhatian terperinci, orientasi pada hasil, orientasi individu, tim dan agresivitas mempunyai nilai mean tinggi yaitu 4,1. Indikator inovasi dan pengambilan resiko memiliki nilai mean tinggi sebesar 4,01, maka PT. Mubarak Ainama Kunt Surabaya mengajarkan sebuah pengambilan keputusan dan pengambilan resiko serta inovasi pekerjaan kepada karyawan berjalan dengan baik.

Indikator perhatian yang terperinci memiliki nilai rata-rata tinggi sebesar 4,17, maka karyawan dapat menunjukkan ketepatan pekerjaannya selalu fokus dan mengerjakan pekerjaannya dengan baik dan benar. Indikator orientasi hasil memiliki nilai rata-rata tinggi sebesar 4,13, maka pimpinan berhasil mengharapkan dan memerintahkan untuk para karyawan agar berfokus pada hasil yang maksimal maka terjadi hasil yang sangat memuaskan.

Indikator orientasi individu memiliki nilai rata-rata tinggi sebesar 4,17, maka manajemen perusahaan PT. Mubarak Ainama Kunt Surabaya dapat memengaruhi orang-orang yang ada dalam perusahaan untuk selalu mengutarakan pendapat dan menggunakan kemampuan dalam bekerja yang dimiliki dengan baik. Indikator orientasi tim memiliki nilai rata-rata tinggi sebesar 4,21, maka perusahan berhasil menekankan kepada karyawannya jika pekerjaan dapat diatur berdasarkan tujuan bersama atau secara tim dan tidak atas kemauan individu saja. Indikator agresivitas mempunyai nilai mean tinggi yaitu 4,05, maka penerapan persaingan antar karyawan dalam bekerja secara sehat dapat berjalan dengan baik.

Tingkat indikator kompetensi pada PT. Mubarak Ainama Kunt Surabaya termasuk dalam golongan yang tinggi. Dari empat indikator yang motif, sifat, pengetahuan, dan keterampilan memiliki nilai mean tinggi yaitu 4,2. Indikator motif mempunyai nilai mean tinggi sebesar 4,27, maka PT. Mubarak Ainama Kunt Surabaya bisa merubah pola pikiran yang diharapkan dapat memberikan rangsangan terhadap tindakan dalam bekerja sehingga tindakan yang diambil karyawan dapat terealisasi.

Indikator sifat mempunyai mean tinggi yaitu 4,21, maka karyawan dapat merespon sesuatu dengan baik terhadap situasi dan informasi yang diterima saat pekerjaan sedang berlangsung. Indikator pengetahuan mempunyai nilai mean tinggi yaitu 4,21, maka dapat ditarik garis besar bahwa karyawan mempunyai banyak informasi terkait bidang pengerjaan melalui pendidikan seperti teori pada buku maupun pengalaman.

Indikator keterampilan mempunyai nilai mean tinggi yaitu 4,12, maka karyawan dari perusahaan PT. Mubarak Ainama Kunt Surabaya mempunyai kemampuan dalam bidang pekerjaannya secara fisik dan juga mental yang baik.

Tingkat organizational citizenship behavior pada PT. Mubarak Ainama Kunt Surabaya merupakan termasuk dalam golongan yang tinggi. Dari lima indikator yang meliputi conscientiousness, altruism, civic virtue, sportsmanship, dan courtesy memiliki nilai mean tinggi yaitu 4,2. Indikator conscientiousness mempunyai nilai mean tinggi yaitu 4,15, maka karyawan PT. Mubarak Ainama Kunt Surabaya mematuhi atasannya dan bekerja sesuai arahan dan aturan di perusahaan.

Indikator altruism mempunyai nilai mean tinggi yaitu 4,27, maka karyawan satu dengan yang lain (rekan kerja) semua saling membantu atau mensupport yang ada kaitannya dengan pekerjaan. Indikator civic virtue memiliki nilai rata-rata tinggi sebesar 4,18, maka sikap keterlibatan karyawan 
dengan perusahaan ini sangat tinggi seperti mengikuti perkembangan perusahaan dan selalu menghadiri kegiatan yang diadakan oleh perusahaan.

Indikator sportsmanship mempunyai nilai mean tinggi yaitu 4,27, maka dapat ditarik garis besar bahwa karyawan berpikiran positif terkait perusahaan ke depannya bagaimana dan tujuan yang dicapai oleh perusahaan sebagai tujuan kita bersama. Indikator courtesy mempunyai nilai mean tinggi yaitu 4,01, maka dapat ditarik garis besar bahwa karyawan berperilaku baik dengan berbuat baik kepada atasan dan berbuat baik dalam pekerjaan yang dilakukan.

Uji Signifikan Parsial/ Individual (Uji Statistik t)

Tabel 1.

UJI STATISTIK T

\begin{tabular}{lccccc}
\hline \multicolumn{1}{c}{ Keterangan } & Beta & t & Sig. & Tolerance & VIF \\
\hline (Constant) & & .037 & .971 & & \\
Kepuasan Kerja & .795 & 10.668 & .000 & .844 & 1.185 \\
Budaya Organisasi & .271 & 3.380 & .002 & .729 & 1.373 \\
Kompetensi & -.102 & -1.341 & .188 & .810 & 1.234 \\
\hline
\end{tabular}

Sumber: Output SPSS

Berdasarkan tabel 1 menunjukkan variabel kepuasan kerja memperoleh nilai signifikansi 0,000 yang lebih kecil dari 0,05. Artinya variabel kepuasan kerja memberikan pengaruh secara signifikan pada organizational citizenship behavior. Diketahui nilai t tabel sebesar 2,02439, serta nilai t hitung sebesar 10,668 terletak pada area pengaruh positif. Terkait demikian Ho ditolak dan Ha diterima. Variabel budaya organisasi memperoleh nilai signifikansi 0,002 yang lebih kecil dari 0,05. Artinya variabel budaya organisasi memberikan pengaruh secara signifikan pada organizational citizenship behavior. Diketahui nilai t tabel sebesar 2,02439, serta nilai t hitung sebesar 3,380 668 terletak pada area pengaruh positif. Terkait demikian Ho ditolak dan Ha diterima. Variabel kompetensi memperoleh nilai signifikansi 0,188 yang lebih besar dari 0,05 . Artinya variabel kompetensi memberikan pengaruh secara signifikan terhadap organizational citizenship behavior. Diketahui nilai $\mathrm{t}$ tabel sebesar 2,02439, serta nilai $\mathrm{t}$ hitung sebesar $-1,341$ terletak pada area tidak ada pengaruh. Terkait demikian Ho diterima dan Ha ditolak.

\section{Uji Signifikan Simultan (Uji Statistik F)}

Tabel 2.

UJI STATISTIK F

\begin{tabular}{cccccc}
\hline & Sum of Squares & df & Men Square & F & Sig. \\
\hline Regression & 350.980 & 3 & 116.993 & 58.427 & $.000^{\mathrm{b}}$ \\
Residual & 76.091 & 38 & 2.002 & & \\
\hline \multicolumn{1}{c}{ Total } & 427.071 & 41 & & & \\
\hline
\end{tabular}

Sumber: Output SPSS

Tabel 2 menunjukkan bahwa nilai signifikansi yang diperoleh adalah 0,000 lebih kecil dari 0,05. Terkait demikian, variabel kepuasan kerja, budaya organisasi, dan kompetensi secara simultan memberikan pengaruh pada kepuasan kerja.

\section{Koefisien Determinasi $\left(\mathrm{R}^{2}\right)$}

Tabel 3 menunjukkan nilai koefisien determinasi ( $R$-Square) yang diperoleh adalah 0,8211 . Hal tersebut menunjukkan bahwa variabel independen yang terdiri dari Kepuasan Kerja, Budaya Organisasi, dan Kompetensi mampu mendeskripsikan 82\% variabel organizational citizenship behavior, sedangkan $18 \%$ dijelaskan oleh variabel lain. 
Khoirul Mahmudi \& Jun Surjanti, Analisis Pengaruh Kepuasan Kerja, Budaya Organisasi dan Kompetensi terhadap Organizational Citizenship Behavior pada PT. Mubarak Ainama Kunt Surabaya

Tabel 3.

R-SQUARE

\begin{tabular}{ccccc}
\hline R & R Square & Adjusted R Square & Std. Error of the Estimate & Durbin-Watson \\
\hline $.907^{\mathrm{a}}$ & .822 & .808 & 1.415 & 1.906 \\
\hline
\end{tabular}

Sumber: Output SPSS

\section{Pengaruh Kepuasan Kerja terhadap Organizational Citizenship Behavior}

Berdasarkan data yang sudah dianalisis, penelitian ini menemukan hasil bahwa kepuasan kerja memberikan pengaruh signifikan secara positif pada organizational citizenship behavior karyawan PT. Mubarak Ainama Kunt Surabaya. Hal ini menunjukkan bahwa semakin maksimal kepuasan kerja di perusahaan akan meningkatkan Organizational Citizenship Behavior yang dialami oleh karyawan PT. Mubarak Ainama Kunt Surabaya.

Hasil analisis deskriptif variabel kepuasan kerja pada karyawan PT. Mubarak Ainama Kunt Surabaya termasuk dalam golongan tinggi. Hal ini karena perusahaan telah memiliki tingkat kepuasan kerja yang baik. Aspek kepuasan kerja yang dibutuhkan karyawan telah terpenuhi seperti rasa aman di tempat kerja di mana PT. Mubarak Ainama Kunt Surabaya memiliki sitem pemberian pengamanan terhadap karyawannya yaitu memberikan pengamanan ekstra dengan disediakannya perlengkapan untuk melindungi diri atau Kesehatan dan keselamatan kerja (K3) dan setiap karyawan diharuskan untuk menggunakan fasilitas dari perusahaan berupa BPJS ketenagakerjaan, maka dapat dipastikan bahwa perusahaan telah memberikan rasa aman yang layak kepada karyawan.

PT. Mubarak Ainama Kunt Surabaya juga memberikan gathering \& out bound sekaligus kepada karyawan untuk mengembangkan kepercayaan antara karyawan dan manajemen atau atasan. Pelatihan dilakukan minimal 1 kali dalam setahun disesuaikan dengan kebutuhan perusahaan. Gathering \& out bound dilakukan di luar perusahaan dengan mengadakan pemusatan diklat bersama-sama dengan seluruh karyawan. Dengan gathering \& out bound yang didapat maka karyawan pastinya memiliki satu pemikiran dan kepercayaan antar karyawan yang lebih baik hingga kepuasan kerjanya dapat meningkat. Untuk menciptakan kepuasan kerja yang maksimal PT. Mubarak Ainama Kunt Surabaya memberikan fasilitas pendukung kepada karyawan seperti laptop pribadi untuk manajer tingkat atas dan disediakan mobil kantor yang digunakan bersama untuk digunakan karyawan level menengah kebawah untuk menunjang mobilitas pekerjaannya karena PT. Mubarak Ainama Kunt Surabaya. Mobil yang disediakan berjumlah 3 unit. Fasilitas lain yang diberikan oleh perusahaan ialah pelatihan yang ditujukan karyawan yang bekerja di luar kantor berupa pelatihan menggunakan alat-alat baru yang belum tentu semua karyawan sudah bisa menggunakan peralatan baru tersebut, hal tersebut dianggap penting karena dapat menjamin kenyamanan di penggunaan peralatan karyawan.

Tngginya kepuasan kerja akan berdampak pada peningkatan organizational citizenship behavior karyawan PT. Mubarak Ainama Kunt Surabaya. Hasil penelitian ini sejalan dengan (Darmawati \& Indartono, 2015), (Dewi \& Suwandana, 2016), (Yasa \& Suandra, 2017), dan (Ramadhan et al., 2018) yang menyatakan penelitian mereka bahwa kepuasan kerja berpengaruh signifikan positif terhadap Organizational Citizenship Behavior. Semakin baik kepuasan kerja di perusahaan maka akan semakin meningkatnya Organizational Citizenship Behavior karyawan di PT. Mubarak Ainama Kunt Surabaya. Akan tetapi penelitian ini tidak sejalan dengan (Heldiane Takaheghesang, Lengkong, \& M.Sendow, 2016) yang menyatakan penelitian mereka bahwa kepuasan kerja berpengaruh negatif terhadap Organizational Citizenship Behavior.

\section{Pengaruh Budaya Organisasi terhadap Organizational Citizenship Behavior}

Analisis data penelitian ini menemukan hasil bahwa budaya kerja memberikan pengaruh signifikan positif pada organizational citizenship behavior karyawan PT. Mubarak Ainama Kota Surabaya. hal ini menunjukkan semakin baik penerapan budaya kerja di perusahaan akan meningkatkan organizational citizenship behavior karyawan PT. Mubarak Ainama Kunt Surabaya. 
Hasil analisis deskriptif variabel budaya organisasi pada karyawan PT. Mubarak Ainama Kunt Surabaya termasuk dalam golongan tinggi. Hal ini karena perusahaan telah memiliki tingkat kualitas budaya organisasi baik. Aspek kualitas budaya organisasi yang dibutuhkan karyawan telah terpenuhi seperti budaya administrasi yang sesuai di mana PT. Mubarak Ainama Kunt Surabaya memiliki sistem administrasi memperlancar para karyawan dalam untuk kegiatan surat menyurat, alur keluar masuk barang, gaji pegawai dan lain sebagainya, maka dapat dipastikan bahwa perusahaan telah memberikan kemudahan dalam budaya organisasi terkait administrasi yang layak kepada karyawan.

PT. Mubarak Ainama Kunt juga memberikan budaya kedisiplinan kepada karyawan untuk mendisiplinkan semua karyawan. Memberlakukan kedisiplinan dilakukan untuk para karyawan yang bekerja di kantor dalam hal ketepatan menyelesaikan order yang diminta, dan memberlakukan tidak telat datang ke kantor dan tempat proyek secara tepat waktu, hal ini sangat penting untuk menjamin budaya organisasi bekerja untuk kepentingan karyawan.

PT. Mubarak Ainama Kunt Surabaya memiliki budaya organisasi terkait pembagian wewenang yang jelas, di mana manajer atau atasan perusahaan yang memberikan wewenang kepada bawahan yang menjadi komponen utama bagi kesuksesan perusahaan, tanpa adanya kewenangan yang jelas dan akurat maka kinerja dari anggota tidak akan berjalan secara maksimal karena terjadi kondisi yang membingungkan. Artinya, semakin baik budaya organisasi yang diterapkan perusahaan akan meningkatkan organizational citizenship behavior karyawan PT. Mubarak Ainama Kunt Surabaya.

Hasil penelitian ini sejalan dengan (Dewanggana, Paramita, \& Andi, 2016), (Utami \& Palupiningdyah, 2016), (Maysarah \& Rahardjo, 2015), dan (Suwibawa et al., 2018) yang menyatakan penelitian mereka bahwa kepuasan kerja berpengaruh signifikan positif terhadap Organizational Citizenship Behavior. Semakin baik budaya organisasi di perusahaan maka akan semakin meningkatnya Organizational Citizenship Behavior karyawan di PT. Mubarak Ainama Kunt Surabaya. Akan tetapi penelitian ini tidak sejalan dengan (Warsito, 2008) yang menyatakan penelitian mereka bahwa kepuasan budaya organisasi tidak signifikan terhadap Organizational Citizenship Behavior.

\section{Pengaruh Kompetensi terhadap Organizational Citizenship Behavior}

Analisis data pada penelitian ini menemukan hasil bahwa kompetensi tidak memberikan pengaruh pada organizational citizenship behavior karyawan PT. Mubarak Ainama Kunt Surabaya. Hal tersebut menunjukkan bahwa kompetensi tidak memberikan pengaruh pada organizational citizenship behavior karyawan PT. Mubarak Ainama Kunt Surabaya.

Hasil uji analisis deskriptif variabel kompetensi pada PT. Mubarak Ainama Kunt Surabaya termasuk dalam golongan tinggi. Hal ini karena pelaksanaan kompetensi karyawan oleh perusahaan berjalan dengan cukup baik. Pelaksanaan pelatihan kompetensi yang dilakukan manajer pada waktu yang tepat dan sesuai dengan kebutuhan perusahaan untuk mencapai tujuan yang akan dicapai. Pelaksanaan kompetensi di PT. Mubarak Ainama Kunt Surabaya dilaksanakan bersifat kondisional sesuai kebutuhan perusahaan tidak terikat oleh kurun waktu tertentu.

Di mana kompetensi yang dimiliki oleh karyawan pada PT. Mubarak Ainama Kunt Surabaya mampu dalam bidang keahliaan pada teknik atau proyek konstruksi. Kondisi ini mengindikasikan bahwa keahlian atau kemampuan karyawan sangat menentukan atas pencapaian atau hasil kerja yang telah ditetapkan oleh perusahaan. Semakin karyawan memiliki suatu keahlian atau kemampuan makan semakin mudah mereka dalam menyelesaikan suatu pekerjaan yang dibebankan oleh perusahaan.

Berdasarkan penjelasan di atas, kompetensi tidak memberikan pengaruh pada organizational citizenship behavior PT. Mubarak Ainama Kunt Surabaya. Dalam wawancara singkat terhadap karywan rara-rata menunjukkan bahwa karyawan memiliki persepsi bahwa kompetensi apapun yang dimiliki ialah hal yang wajar dalam bidang pekerjaan, suatu skill karyawan dibidang kerja manapun tetap membuat perilaku karyawan merasa puas dengan pekerjaaan yang dijalani. Artinya karyawan 
Khoirul Mahmudi \& Jun Surjanti, Analisis Pengaruh Kepuasan Kerja, Budaya Organisasi dan Kompetensi terhadap Organizational Citizenship Behavior pada PT. Mubarak Ainama Kunt Surabaya

tersebut baik berkompetensi atau tidak maka tidak akan memberikan pengaruh pada organizational citizenship behavior karyawan, di mana mereka akan tetap bersedia membantu sesama rekan kerja atau tidak. Penelitian ini menunjukkan hasil bahwa banyak karyawan yang tidak bekompetensi namun tetap memiliki kemauan untuk membantu dari segi tenaga atau ide ke karyawan lain.

Hasil penelitian ini sejalan dengan (Suhardi \& Syaifullah, 2017) dan (Adianita et al., 2017) yang yang menyatakan bahwa kompetensi tidak berpengaruh signifikan terhadap Organizational Citizenship Behavior. Baik atau buruknya pelaksanaan kompetensi yang dilakukan oleh PT. Mubarak Ainama Kunt Surabaya tidak memberikan pengaruh terhadap Organizational Citizenship Behavior yang dirasakan karyawan. Akan tetapi penelitian ini tidak sejalan dengan (Suhardi \& Syaifullah, 2017), (A. Kurniawan, 2014), dan (Priyono et al., 2016) yang menyatakan penelitian mereka bahwa kompetensi berpengaruh terhadap Organizational Citizenship Behavior.

\section{Pengaruh Kepuasan Kerja, Budaya Organisasi, dan Kompetensi terhadap Organizational Citizenship Behavior}

Hasil uji analisis deskriptif nilai mean variabel kepuasan kerja yang termasuk dalam golongan tinggi, variabel budaya organisasi dengan nilai mean yang termasuk dalam golongan tinggi, variabel kompetensi dengan nilai mean yang termasuk dalam golongan tinggi, variabel Organizational Citizenship Behavior dengan nilai mean yang termasuk dalam golongan tinggi.

Berdasarkan hasil penelitian diketahui bahwa skor tinggi terletak pada indikator pernyataan kepuasan terhadap atasan. Hal ini ditunjukkan dari sikap pimpinan PT. Mubarak Ainama Kunt Surabaya di lapangan yang selalu melakukan perintah dan memberikan petunjuk terlebih dahulu terhadap masalah atau pekerjaan yang karyawan hadapi. Selain itu indikator pernyataan orientasi tim diketahui bahwa skor tinggi. Hal ini ditunjukkan dengan sikap para karyawan di lapangan bahwa suatu pekerjaan itu dapat diatur berdasarkan pada tujuan bersama para karyawan dan bukan atas kemauan per individu saja. Sedangkan pada hasil penelitian ini juga diketahui bahwa skor tinggi terdapat pada indikator pernyataan sifat. Hal ini dapat ditunjukkan dengan kondisi fisik karyawan dan juga respon yang konsisten terhadap situasi pekerjaan dan informasi pekerjaan yang diterima.

\section{KESIMPULAN}

Hasil penelitian menunjukkan bahwa kepuasan kerja memberikan pengaruh signifikan positif pada organizational citizenship behavior. Menunjukkan bahwa tingginya kepuasan kerja akan berdampak pada peningkatan organizational citizenship behavior karyawan PT. Mubarak Ainama Kunt Surabaya. Budaya organisasi memberikan pengaruh signifikan positif pada organizational citizenship behavior. Menunjukkan bahwa budaya organisasi yang diterapkan perusahaan akan meningkatkan organizational citizenship behavior karyawan PT. Mubarak Ainama Kunt Surabaya. Kompetensi tidak memberikan pengaruh signifikan pada organizational citizenship behavior. Menunjukkan bahwa baik atau buruknya pelaksanaan kompetensi di lingkup perusahaan tidak memengaruhi peningkatan atau penurunan organizational citizenship behavior karyawan pada PT. Mubarak Ainama Kunt Surabaya.

Pengembangan yang dapat dilakukan terkait penelitian ini dapat berupa aspek pemberian, inovasi, dan pengambilan resiko perlu ditingkatkan lagi agar karyawan semakin memberikan kontribusi inovasi yang lebih terhadap perusahaan dan mampu mengambil sebuah resiko saat pekerjaan apapun yang dilakukan. Perusahaan harus memberikan penjelasan tertulis maupun praktek pelatihan ringan kepada karyawan setiap bulan agar karyawan memiliki banyak keterampilan akan memberikan dampak positif kepada pekerjaannya serta memerhatikan sopan santun karyawan dengan manajer atau atasan guna meningkatkan kepercayaan dalam menjalankan pekerjaan yang diberikan manajer atau atasan. Penelitan yang akan datang diharapkan menambahkan variabel moderasi yakni disiplin kerja mengingat resiko pekerjaan yang dihadapi oleh karyawan cukup tinggi dan terdapat kecelakaan kerja yang menimbulkan korban jiwa, agar dapat melakukan pengembangan penelitian yang memengaruhi kuat lemahnya organizational citizenship behavior. 


\section{DAFTAR PUSTAKA}

Adianita, A. S., Mujanah, S., \& Candraningrat, C. (2017). Kompetensi Karyawan, Emotional Quotient Dan Self Efficacy Pengaruhnya Terhadap Organizational Citizenship Behavior Dan Kinerja Karyawan Pada Indomobil Grup Di Surabaya. Jurnal Riset Ekonomi Dan Manajemen, 17(1), 199.

Darmawati, A., \& Indartono, S. (2015). Pengaruh Kepuasan Kerja Terhadap Organizational Citizenship Behavior Dengan Komitmen Organisasi Sebagai Variabel Mediasi. Jurnal Ilmu Manajemen, 12(2), 49-64.

Dewanggana, B. D., Paramita, P. D., \& Andi, T. H. (2016). Organisasi Terhadap Organizational Citizenship Behavior ( OCB ) Yang Berdampak Pada Prestasi Kerja Karyawan. Journal of Management, 2(2), 1-10.

Dewanggana, B. D., Paramita, P. D., \& Haryono, A. T. (2016). Pengaruh Komitmen Organisasi, Kepuasan Kerja, Budaya Organisasi Terhadap Organizational Citizenship Behavior (OCB) Yang Berdampak Pada Prestasi Kerja Karyawan (Studi pada PT. PLN APP Semarang). Journal Of Management, 2(2), 1-10.

Dewi, N. L. P. Y. A., \& Suwandana, I. G. M. (2016). Pengaruh Kepuasan Kerja Terhadap Organizational Citizenship behavior (OCB) Dengan Komitmen Organisasional Sebagai Variabel Mediasi. E-Jurnal Manajemen Unud, 5(9), 5643-5670.

Fattah, H. (2017). Kepuasan Kerja \& Kinerja Pegawai; Budaya Organisasi, Perilaku Pemimpin dan Efikasi Diri. Yogyakarta: Anggota IKAPI.

Heldiane Takaheghesang, Lengkong, V. P. K., \& M.Sendow, G. (2016). Analisis Pengaruh Kepuasan Kerja, Komitmen Kerja, Pemberdayaan Psikologis dan Kepemimpinan Transformasional Terhadap Organizational Citizenship Behavior (OCB) Pada Karyawan PT Jasa Raharja (Persero) Manado. Jurnal EMBA, 4(4), 1013-1024.

Huda, M. (2018). Pengaruh Budaya Organisasional dan Komitmen Organisasional Terhadap Kinerja Karyawan dengan Organizational Citizenship Behavior (OCB) sebagai Variabel Intervening (Pada Karyawan tetap Fakultas Ekonomi Universitas Islam Indonesia). 1-31.

Husodo, Y. R. P. (2018). Pengaruh Budaya Organisasi Terhadap Organizational Citizenship Behavior (OCB) Dengan Kepuasan Kerja Sebagai Variabel Intervening Pada PT Jatim Indo Lestari. AGORA, 6(1), 1-8.

Kurniawan, A. (2014). The Influence of Competency and Commitment to Organizational Citizenship Behavior and Its Impact to Employee Productivity Based on Perception of Supervisors : A Survey at Star Hotels in West Java. Journal of Business and Economics, 5(8), 1430-1441.

Kurniawan, D. A., Guswandi, \& Sodikin, A. (2018). The Effect of Competence and Motivation on Employee Performance Through Employees Capabilitieson PT. Bersinar Amity. International Journal of Research Science \& Management, 5(5), 48-60.

Maysarah, S., \& Rahardjo, M. (2015). Analisis Pengaruh Budaya Organisasi, Keadilan Organisasi, dan Komitmen Organisasional Terhadap Organizational Citizenship Behavior (Studi Pada PT Kereta Api Indonesia (Persero) Daerah Operasi 4 Semarang). Diponegoro Journal of Management, 4(4), 1-14.

Mulyadi, Y., \& Sembiring, J. (2016). Pengaruh Faktor-Faktor Budaya Organisasi Menurut Denison Terhadap Learning Organization Di PT Akses Nusa Karya Infratek Bandung. E-Proceeding of 
Khoirul Mahmudi \& Jun Surjanti, Analisis Pengaruh Kepuasan Kerja, Budaya Organisasi dan Kompetensi terhadap Organizational Citizenship Behavior pada PT. Mubarak Ainama Kunt Surabaya

Management, 3(3), 3056-3063.

Nugraha, I. P. S., \& Adnyani, I. G. A. D. (2018). Pengaruh Budaya Organisasi, Komitmen Organisasi, Dan Kompetensi Terhadaporganizational Citizenship Behaviour Pada Setda Kota Denpasar. EJurnal Manajemen Unud, 7(1), 1-28.

Oemar, Y. (2013). Pengaruh Budaya Organisasi, Kemampuan Kerja dan Komitmen Organisasi terhadap Organizational Citizenship Behavior (OCB) Pegawai pada BAPPEDA Kota Pekanbaru. Jurnal Aplikasi Manajemen, 11(66), 65-76.

Osman, A., Othman, Y. H., Sohel Rana, S. M., Solaiman, M., \& Lal, B. (2015). The influence of job satisfaction, job motivation \& perceived organizational support towards organizational citizenship behavior (OCB): A perspective of American-Based Organization in Kulim, Malaysia. Asian Social Science, 11(21), 174-182.

Pattiasina, M., Roring, M., \& Rumawas, W. (2016). Pengaruh Kompetensi Sumber Daya Manusia Terhadap Kinerja Karyawan PT.Bank Tabungan Negara, Tbk. Kantor Cabang Manado. Jurnal Administrasi Bisnis, 1-6.

Pianda, D. (2018). Kinerja Guru; Kompetensi Guru, Motivasi Kerja, Kepemimpinan Kepala Sekolah. Sukabumi: CV Jejak.

Priyono, B. S., Soliha, E., Rijanti, T., \& Gusman, R. (2016). The Influence Of Competency and Movation to Employee Performance With Organizationel Citizenship Behavior As Moderating Variabel (Study on Traficc Accident Investigators, Central Java Police Department). Proceedings-International Conference of Banking, Accounting, Management and Economics \& Call For Papers (ICOBAME), 978-979.

Ramadhan, N., Saudi, M. H. M., \& Yenni. (2018). Effect of Employee Job Satisfaction on Organizational Citizenship Behavior at Effect of Employee Job Satisfaction on Organizational Citizenship Behavior at Assessment Center Indonesia. International Journal of Engineering \& Technology, 4(34), 253-256.

Rande, D. (2016). Pengaruh Kompetensi Terhadap Kinerja Pegawai Pada Dinas Perhubungan, Komunikasi Dan Informatika Kabupaten Mamuju utara. E Jurnal Katalogis, 4(2), 101-109.

Suhardi, \& Syaifullah. (2017). Pengaruh Motivasi, Kompetensi, Lingkungan Kerja, Kompensasi Terhadap Organizational Citizenship Behavior dan Kinerja Karyawan Asuransi Jiwa Di Provinsi Kepualan Riau. Jurnal Benefita, 2(1), 55-71.

Suwibawa, A., Agung, A., Agung, P., Ketut, I., \& Sapta, S. (2018). Effect of Organizational Culture and Organizational Commitment to Employee Performance through Organizational Citizenship Behavior (OCB) as Intervening Variables (Study on Bappeda Litbang Provinsi Bali) Corresponding Author: Emmanuel Ifeanyi Orji Anom Suw. International Journal of Contemporary Research and Review, 9(8), 20997-21013.

Syaroni, B. (2015). Kinerja Pelayanan Publik Dinas Pendidikan (Survei di Dinas Pendidikan SeWilayah III Cirebon). Yogyakarta: Deepublish.

Utami, R. M., \& Palupiningdyah. (2016). Pengaruh Kepuasan Kerja, Budaya Organisasi dan Keterlibatan Kerja pada Organizational Citizenship Behavior. Management Analysis Journal, 5(4), 362-374.

Utaminingsih, A. (2014). Perilaku Organisasi. Malang: UB Press. 
Warsito, B. (2008). Pengaruh Budaya Organisasi dan Lingkungan Kerja Terhadap Organizational Citizenship Behavior, Motivasi dan Kinerja. Jurnal Ekonomi Modernisasi, 4(2), 83-96.

Yasa, P. N. S., \& Suandra, Y. K. (2017). The Influence of Job Satisfaction on Organizational Citizenship Behavior through the Mediation of Organizational Commitment ( A Case Study in the Westin Resort Nusa Dua, Bali ). Journal of Law, Policy and Globalization, 57, 64-74. 